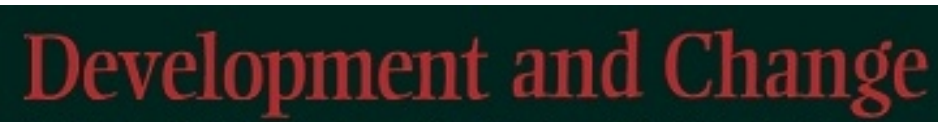

Published on behalf of the International Institute of Social Studies, The Hague

Internationa

Institute of

Social Studies

\title{
Social Policy, Inequalities and the Battle of Rights in Latin America
}

\begin{tabular}{|c|l|}
\hline Journal: & Development and Change \\
\hline Manuscript ID & DECH-19-431 \\
\hline Meywords: & $\begin{array}{l}\text { Social policy < General, Latin America, post-neoliberalism, socio- } \\
\text { economic vs ecological spheres, citizenship }\end{array}$ \\
\hline Abstract: & $\begin{array}{l}\text { Targeted social policies and other more 'universal' forms of social } \\
\text { protection have shaped the (shifts in) politics of popular support in Latin } \\
\text { America. Since the early 2000s this has played into tendencies toward } \\
\text { left-leaning governments stimulating stronger political pressures for } \\
\text { more extensive redistribution. Yet despite a wide range of cash transfers, } \\
\text { struggled to reshape the political and relational powers of citizens in the } \\
\text { ways necessary to redress structural determinants of poverty and } \\
\text { inequality across the region. This paper reveals a 'dark side' of social } \\
\text { policy in Latin America arguing that targeted and precariously funded } \\
\text { welfare regimes are creating tensions between 'socio-economic' and } \\
\text { 'ecological' spheres that undermine inclusive citizenship and democracy. }\end{array}$ \\
\hline
\end{tabular}




\title{
Social Policy, Inequalities and the Battle of Rights in Latin America
}

Pia Riggirozzi

University of Southampton

P.Riggirozzi@soton.ac.uk

\begin{abstract}
Targeted social policies and other more 'universal' forms of social protection have shaped the (shifts in) politics of popular support in Latin America. Since the early 2000s this has played into tendencies toward left-leaning governments stimulating stronger political pressures for more extensive redistribution. Yet despite a wide range of cash transfers, subsidies, and other social policies, the 'post-neoliberal' ideal of welfare struggled to reshape the political and relational powers of citizens in the ways necessary to redress structural determinants of poverty and inequality across the region. This paper reveals a 'dark side' of social policy in Latin America arguing that targeted and precariously funded welfare regimes are creating tensions between 'socio-economic' and 'ecological' spheres that undermine inclusive citizenship and democracy.
\end{abstract}

\section{Introduction}

In the early 1990s, as Latin America emerged from the challenges marked by a decade of debt crisis and hyperinflation, social programmes were set to expand and improve health care, education services, and pension coverage while a strong appreciation of the imperative of macroeconomic stability privileged cost-effective and financially sustainable social assistance together with a focus on the most needy in society. A decade later, social policy underwent a significant transformation providing an opportunity where a new language of rights expanded existing welfare programmes and supported a 'post-neoliberal' ideal of welfare as instrumental to how society should function (Esping-Andersen 1999: 36) but where social policies become themselves frameworks for empowerment and change (Grugel and Riggirozzi 2012; 2018).

Despite new forms of political activism and partial transitions towards more inclusive societies, the 'post-neoliberal' ideal of welfare got stuck in a distributive paradigm that struggled to redefine the terms of the neoliberal sufficiency-based model aimed at prioritising the poorest and ensuring basic needs were met. Moreover, while important wins were associated with social development through the articulation of more inclusive welfare strategies, these became increasingly dependent on an intensive exploitation of natural resources that not only generated an inflow of revenue for 
socioeconomic development but also created perverse incentives that often led to violent forms of dispossession and repressive legislation affecting rural and indigenous communities' demand for land reform and environmental justice in particular. In the end, the political and relational shift in power necessary to redress structural determinants of poverty and inequality were difficult to embed in an alternative welfare paradigm across the region. Delivering welfare in the face of resource rents meant that progressive governments have been more successful in putting in motion social policies to reduce socio-economic inequalities than in addressing other forms of identity/ethnically based exclusion.

What this reveals, this article argues, is a 'dark side' of welfare policy in current Latin America. This dark side is defined by a tension between 'socio-economic' and 'ecological' spheres, ${ }^{1}$ where the right to a social benefit becomes captured by and transformed into a logic that has fuelled the domestic consumer market as part of a socio-development strategy (Singer 2012: 147; Lavinas 2013; 2018) while defending human and environmental rights has been left unaddressed. Such tensions define a narrow and segregated logic of (rights to) welfare that is difficult to reconcile with any definition of substantive, inclusive democracy.

This article looks at these tensions in the context of Latin American social policies and draws attention to three inter-linked themes: (i) the challenges of expanding citizenship in democracy, where social policies are expected to counteract market pressures and austerity; (ii) revenue bargaining between governments and citizens and effective state capacity in advancing social transformation; and (iii) the potential for targeted and precariously funded welfare regimes to undermine citizenship and inclusive democracy.

\section{Inequalities, Uneven Inclusion and Weak Foundations of Welfare in Latin America}

In Latin America, welfare regimes are deeply rooted in early social policy and labour policies that predicted a model of full employment, with formalised workers fully engaged as regular tax payers, with business opportunities registered with the state, and constant influx of contributions from a formal sector that can generate enough income for states to deliver the kind of benefits that support the reproduction of that model. This

\footnotetext{
${ }^{1}$ I thank the Editors for comments and an anonymous reviewer for this suggestion
} 
model of state-society relations and political economy that resonates with the classic view of welfare never fully emerged. The expectations were based on industrialisation, formalisation and widespread unionisation of workers, and large state sector employment; while import substitution would create a strong labour force that would reproduce a model of inclusion and growth. This was a project of 'national' development enshrined in the prescriptions and policies of the Economic Commission for Latin America and the Caribbean (ECLAC) that was rapidly disseminated after the 1940s (Lewis 2018). European social models were highly influential in the 1950s and 1960s in the Southern Cone countries of Brazil, Argentina, Chile and Uruguay, where import substituting industrialisation created a sizable formal labour force and political parties that represented the urban working and middle classes (Huber and Stephens 2012). Import substitution industrialisation would also up-grade domestic enterprise by means of demand management and societal modernisation (Haggard and Kaufman 2008). Politically elites aspired to social democratic-type welfare systems and social policy provision through social insurance. By the end of the 1970s, in Chile, Brazil, Uruguay and Argentina the share of the labour force in formal employment covered by social insurance schemes reached over 70 per cent (Barrientos 2009: 7). Elsewhere in Latin America, welfare was far more limited in scope. Although insurance schemes and state investments in education and public health expanded from the 1940s, the principal beneficiaries were the urban middle classes and, to a lesser extent, the working class in the cities, leaving rural and indigenous communities with poor service provision and little welfare coverage. In addition, import substitution industrialisation did not create enough jobs to absorb the mass mobilisation of workers that it encouraged towards the main cities. The distribution of economic and social opportunities in the city proved deeply uneven leading to two increasing challenges: Latin American cities started to be divided between its urban centres and slums with residents of the latter spaces having far worse access to public infrastructure, social services and formal employment opportunities than other urban residents (Garay 2017). Equally, the lack of absorption in formal employment steadily created a mass of workers vulnerable to informal employment, with poor labour conditions and limited access to skill upgrading and social rights, and unemployment (Martínez Franzoni and Sánchez-Ancochea 2016). The urban informal sector reached 45.9 per cent of the workforce in Latin America in the last decade of the twentieth century (Portes and Hoffman 2003: 49, 53). 
The problem was that expectations of national economic growth through import substitution industrialisation to have a system that pays for itself were never realised and the actual development of the national economy saw the emergence of classes of workers that never participated politically and were at the margins of representation in political parties or labour unions. Economically the model was highly dependent on the ability to build a solid scientific technological base but this construction was truncated by the incapacity to reverse the lag in industrial development along with lags in education and the even greater technological backwardness of the region (Ocampo 2013).

Politically, the system was built around a concept of inclusion and representation through political parties, into government jobs and public services that supported the labour market, and increasingly powerful labour unions - often tightly bound to political parties - that reproduced citizen incorporation through a labour based system. At the same time a state bureaucracy developed to respond to rising demands from the increasingly unionised and mobilised formal sector workers. Social policy development was thus related to the power of formal labour organisations and their ability to obtain concessions, and to the ambitions and capacity of administrations to respond to labour demands, and /or to mobilise political support (Collier and Collier 1991; Garay 2017).

In this context, the region's long-standing social policies reproduced an uneven inclusion amounting to a welfare system in which the formally employed middle classes have access to social policies such as health insurance, tertiary education, and pensions, while those citizens working in the informal sector and the extreme poor have been left out of such entitlements (Garay 2017). For instance, in highly unionised labour markets such as Argentina, Chile, Uruguay, and to a large extent Brazil, social security developed as restricted in scope, owing to its association with formal employment and in many cases a corporatist association. In addition, the coverage even of basic educational and health services was low up to the end of the 1990s (also Bértola and Ocampo 2012). The result was segmented and weak welfare systems which spread its benefits to some middle sectors of society while a large share of the urban informal sector with no proper contract or social security, the rural and non-industrialised workers and the unemployed remained in poverty across the region (Barrientos 2004; Martinez Franzoni and Sanchez Ancochea 2014). As the 'left behind' lacked policy entitlements and consistent and meaningful political inclusion, they became locked into a cycle of poverty and at risk of 
marginalisation, not being able to organise collectively due to their heterogeneous and often fragmented working conditions, and often subject to, and dependent on, personalised and politicised hand-outs. As a result, uneven inclusion and frustrated aspirations to universalism became a hallmark of democracy in Latin America (Pribble 2013).

\section{The Politics of Redistribution and Social Change}

Transitions to democracy in Latin America after the 1980s and liberal trends during the 1990s have created pressures to reform the corporative social insurance model perceived to be inefficient and expensive. Neoliberal restructuring spanned across the region as a direct consequence of hyperinflation and debt crisis, liberalising international trade and investment, privatising public services and enterprises, and retrenching social spending under pressures from international financial institutions (Weyland 2004). The fate of neoliberalism and its promise of more competitive states meant that welfare spending came under criticism for creating a fiscal burden, as well as, morally, for creating 'wrong' incentives to avoid social obligations, discouraging ambition of those who rather than paying for it, depend on welfare benefits (Cox 1998: 8).

The end game of social policy changed. Rather than promoting a collectivisation of social risk, the new social policy paradigm accepted that the poor would face greater insecurity because of market opening and trade union reform, sought to encourage them not evade their social obligations and avoided 'unnecessary' welfare spending (Stampini and Tomarolli 2012). Values of selectivity and individual responsibility replaced those of universality; which modified expectations about welfare as universal aspiration towards pragmatic ideals of how society should function. Social policy changed to small-scale, pro-poor targeted programmes to address extreme poverty (Barrientos 2004).

State-roll back of welfare cut into all forms of state protection and left individuals and communities more exposed to risk and the market. Public spending cuts discouraged universal programmes in favour of more selective, efficient way of 'targeting' beneficiaries. The welfare system was now conditioned to a hierarchical model of inclusion and a residual model of policy based on 'eligibility' to basic, publicly provided, welfare entitlements dependent upon an individual's agreement to meet 
particular compulsory social duties or behaviour (Deacon 2002). States increasingly shifted from aspirations to universalism in the provision of care, health and education as social rights, to the provision of transfer-based programmes such as subsidies, cash transfers, and public employment programmes to key people who did not reach a basic needs threshold, or were affected by economic and social dislocations from trade or financial reforms and austerity measures. Ironically, innovation in social policy was stimulated not by democratic transformation, but by the imperatives of a politically sensitive context in which the 'good state' implemented policies aimed at diminishing the negative effects of structural adjustment policies while ensuring stability and preventing social backlash against market-oriented reforms (Nooruddin and Rudra 2014). Between 1980 and 1999 the number of people in Latin American living in poverty grew from just under 136 to over 211 million. In the same period, Latin America experienced more than forty episodes of currency crisis, during which GDP fell by four percent or more and casualisation of labour and unemployment increased dramatically (ECLAC 2010: 12). According to the ILO (2018) six out of 10 jobs created in the 1990s in Latin America were informal, and despite significant growth since mid2000s by 2016 informal employment affected 140 million workers in Latin America and the Caribbean, that is 53.8 per cent of total agricultural and non-agricultural employment.

Concerns over the social costs and the political sustainability of adjustment strategies prompted governments throughout the region, with support from IFIs, to introduce targeted anti-poverty programmes. Linking socio-economic shifts to the big picture of politics is especially important at moments of welfare expansion and policy innovation. As such, the creation and expansion of welfare and targeted pro-poor programmes could be seen as a reaction to the social consequences of market reforms and to politicians' further incentives to win over excluded population (Garay 2017; Borges 2018). In other words, it soon became evident from a governance perspective that the neoliberal project of economic restructuring, opening of markets, free trade and contraction of the state, needed to address the social question, particularly the consequence of reforms on social protection and the relief of poverty; or what Molyneux (2007:12) identified as a combination of 'thick' and 'thin' liberalism. Notably, centre-right President Ernesto Zedillo (1994-2000) in Mexico was first to launch Progresa/Oportunidades in 1997, followed by Brazilian centrist president Fernando Henrique Cardoso (1995-2003) who 
introduced Bolsa Escola in 2001. Both programmes became an iconic modality of social assistance: rather than transferring income to the poor through price subsidies, food stamps, or direct distribution of foodstuffs, policy makers and market-based actors, including international financial institutions, supported conditional cash transfer programmes (CCT), a direct monetary transfer to support poor families. CCT were designed as income-support and safety net schemes in the form of monthly allowances targeted above all at the poorest households and contingent on school attendance and medical checkups as a way to improve human capital (Stampini and Tornarollo 2012). This was considered a cost-effective way of combining the principle of pro-poor targeting with a goal of improving 'human capital', consistent with the 'logic of the market' and likely to avoid distortions of relative prices such as social benefit schemes based on direct handouts or subsidies (Rawlings and Rubio 2003; Solimano 2004).

But Latin American democracies struggled to reconcile political and social inclusion in this environment. The costs of restructuring the welfare state towards a reliance on global financial markets are well acknowledged (IADB 2006; Solimano and Soto 2005) and led directly to social deterioration and political turmoil. The rise of the 'new Left' governments in Venezuela (1998), Brazil (2002), Argentina (2003), Uruguay (2004), Bolivia (2005), Ecuador (2006), Nicaragua (2007) and, for shorter periods, in Paraguay (2008), El Salvador (2009) and Peru (2011) promised the beginning of a neoliberal rollback. Above all, new governments offered a politics of hope to citizens made vulnerable through marketisation and uncertainty in a context of rising levels of poverty and inequality (Londono and Szekely 1997; Grugel and Riggirozzi 2012). The various coalitions that made up the Left were rooted in anti-austerity protests and the promise to break with neoliberal political economies (Yashar 2011). As a political project, it promised to uphold the dignity and rights of all citizens in the face of markets.

The extent to which the so-called 'post-neoliberalism' represented a genuine alternative shifting from the neoliberal sufficiency-based model for the poorest to new forms of inclusive and distributive welfare is subject of contentious debate. The new Left was after all a remarkable attempt to refocus the economy in order to combine growth, fiscal stability and some forms of income redistribution within the context of capitalist economies (Grugel and Riggirozzi 2012). In terms of social policy, without 'ceding' forms of neoliberalism, the new Left made a pragmatic choice of extending and reframing cash transfer programmes of the neoliberal era as the main means for 
redistribution of income (Papadopoulos and Velázquez Leyer 2016). New ideas and commitments to greater inclusion and recognition of human rights transformed the language around how the duties of the state itself were understood, shifting welfare responsibilities from the individual to the public sphere. Welfare provision under the Left in Latin America has gone beyond engineering behavioural change or the provision of minimal safety nets, in the manner typical of neoliberal welfare. Instead, there is evidence of social policies based on ideas of socio-economic and identity rights. Since being pioneered by Brazil and Mexico in 1997 CCTs programmes have acquired unprecedented significance for public policies to overcome poverty in the region, extending today to as many as 30 such programmes across Latin American countries (Cecchini and Atuesta 2017). Coverage also expanded exponentially to include families in rural areas, with school-age children, pregnant women and women with care responsibilities for disabled people (Lavinas 2013: 9; Sandberg 2016: 319; Grugel and Riggirozzi 2018).

In Argentina, the left government of Cristina Fernandez de Kirchner (2006-2015) introduced a non-contributory targeted programme for children, the Universal Child Benefit (Asignación Universal por Hijo or AUH) in 2010. AUH provides a monthly allowance for nearly 4 million children and families conditioned upon schooling and health targets, mainly vaccination (UNICEF 2018). The programme is significant in that, for the first time, the government extended welfare directly to children and to nonunionised workers, mainly female. Likewise, Bolivia's first nationwide CCT, the Bono Juancito Pinto, introduced in 2006 turned the focus to public school children. Bono Juancito Pinto is a universal programme that makes every child enrolled in a public school, regardless of household income, eligible for an annual stipend of approximately US\$28 on the condition of school attendance. Bolivia also introduced the Bono Juana Azurduy targeting pregnant women and new mothers in 2009. It provides up to US \$260 per beneficiary, with cash payments for up to four prenatal medical visits; for giving birth attended by trained personnel, acquiring a birth certificate for the baby, and getting a week of post-partum medical monitoring; and for taking the baby up to twelve checkups spaced at two month intervals over a two-year period (McGuire 2013). Grugel and Riggirozzi (2018) explored the inroads that Uruguay has made in terms of social policy to revert disadvantaged positions associated with gender. In this context, a new national system of care (Sistema Nacional de Cuidados) introduced in 2012 strengthens gender 
rights and recognition of the unequal burden of care implementing a cash-for-care system for home-based services, day-care centres for children and residential and nursing homes for the elderly, in addition to regulations regarding paid parental leave and financial support for carers' work (Matus Lopez and Cid Pedraza 2016). Likewise, in Ecuador, the introduction of policies to support disabled people via the Discapacidades programme promoted new modalities of social and financial inclusion of people with disabilities and supports their participation in society (Grugel and Riggirozzi 2018).

The number of individuals living in recipient households increased from fewer than 1 million in 1996 to 131.8 million in 2015 , or $20.9 \%$ of the regions total population (see figure 1).

Figure 1: Latin America and the Caribbean: Population of households participating in CCT programmes, 1996-2016

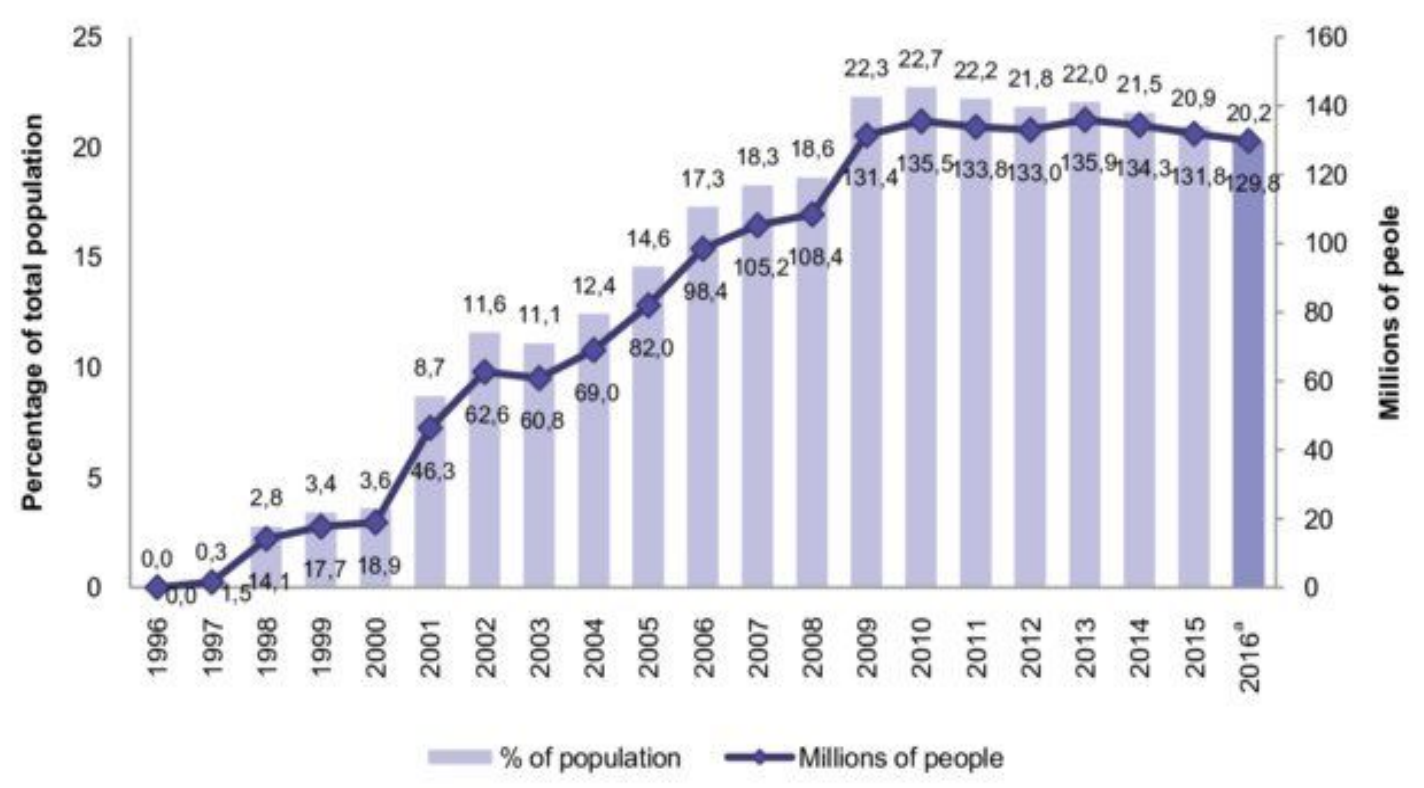

Source: Cecchini, S. and B. Atuesta (2017: 22)

There is a wealth of work showing that CCT programmes have increased household consumption, and reduced poverty and inequality (Cecchini and Atuesta 2017; Molina Millan et al 2016). Oportunidades in Mexico and Bolsa Familia in Brazil show a reduction of inequality of around 2.7 points in both cases (Hall 2008; Amarante and Brun 2016). Schooling, health and infant nutrition also improved significantly (Cecchini 
and Veras Soares 2014). Likewise, the AUH in Argentina has provided since 2009 a monthly allowance per child to households whose members are unemployed or working in the informal sector (Garganta et al 2017). The AUH covers around 30 per cent of all children under 18 years and more than two million families in Argentina, that is 15 per cent of total households in the country (ibid). Politically, the high level of institutionalisation meant that CCT implementation and monitoring is less attached to a required social organisation or political broker (Zucco 2013; Garay 2017). In addition, other non-contributive programmes were aimed at paying pensions to elderly people, including rural pensions in Brazil, the 'Income Dignity' programme (Renta Dignidad) in Bolivia (non-contributive and universal), and the universal and unconditional pension in Mexico. Argentina extended pension schemes for new beneficiaries into its pension schemes for citizens who failed to pay entirely or part of social security contributions during working life, including women in the care economy and informal workers or unemployed (Arza 2012). From the early 2000s, Latin America also embarked in extensive workfare and the introduction or increase of minimum wages programmes (see CEPAL https://dds.cepal.org/bpsnc/lpi). These programmes led to a significant improvement of jobs in the formal market and a redistribution in favour of low-paid workers, and a significant revalorisation of wages that for example in Brazil grew in real terms by almost 70 per cent between 2003 and 2014 (Borges 2018). Income inequality in the 2000s significantly declined in the majority of countries. From an average of 0.530 in the late 1990s, the Gini coefficient for household per capita income fell to 0.497 in 2010; 20 per cent of this fall being attributed to cash transfers and 60 per cent to a decline in wage inequality (Lustig et al 2012).

Overall, what the above suggests is that in relative terms the greatest benefits of postneoliberal social policy has accrued some important wins in terms of addressing poverty and inequality based on a move from the neoliberal sufficiency model towards a wideranging model based on recognition and rights. But the cons are there, too: Lavinas $(2013$; 2017) argues that while these programmes made progress in terms of coverage, including informal workers, establishing CCT programmes that condition cash transfer to schooling and medical visits, typically mothers sending their children to school and health visits the quality of supply of health services and education remained underfunded and inadequate. Moreover, a perverse dynamic seems to emerge from the focus on behaviour where the responsibility for improving health and education is 
imposed on those who are supposedly in need of assistance assuming that the poor should be encouraged to 'help themselves' to participate in society (Cornwall 2003). This supports Handa and Davis (2006) argument about stigmatisation of poverty and public attitudes to it as an individual failure, individual lack of effort or responsibility.

Likewise, Lavinas and Simões (2015); Saad-Filho (2015) and Lavinas (2017) contend that the core of this welfare model is still based on aggregate demand with severe implications for increased household consumption and debt (see also Lazzarato 2012). This is particularly problematic for those who may have entered the ranks of formal employment but are still threatened by job insecurity and informality, as well as for unprotected groups of population, including a large and growing share of the middleclass, potentially not eligible to receive social assistance in case of hardship yet vulnerable to economic changes and risk of falling (back) into poverty (Ocampo and Gomez-Arteaga 2016).

Finally, there is an element of re-politicisation of conditional cash transfer and other social protection programmes that point not just to the ideological bases of change but fundamentally to the (lack of?) effectiveness of anti-poverty strategies. However, the question this article places is not so much whether these progammes 'work', empirically speaking, or whether they genuinely represent a break from neoliberal forms, but rather turns the attention to the capacity of governments to send a signal through its expenditure and policies more generally that the state will not only protect the very poor but will, more broadly, arbitrate effectively between the interests of different social groups and deliver social justice, rather than be captured by elite groups. This question builds on the fact that the expansion of welfare schemes was funded by taxes on resources exports during the commodity price boom years between 2003-2007 and improved terms of trade that supported economic growth and increased tax/GDP ratio (Levitsky and Roberts 2011; Murillo, 2011: 54; Remmer 2012; Postero 2013: 40). The problem was that the Left seized on growth as a way to make more strategic distributive spending, yet created something of a trap for itself by reinforcing dependency on growth based on the export of primary goods that led to a tension between the state as the administrator of income and distribution, and the political influence of the extractive class fractions, such as mining elites and large landowners. In this context, granting welfare and rights to citizens became a political battle contingent on the domestic bargain between actors and the fiscal challenge built into this model. 


\section{The Injustices of Welfare}

Traditionally, welfare in Latin America has been limited in reach by difficulties in collecting income tax and taxes on assets and wealth, due to non-compliance, tax avoidance, and concessions to foreign investors, as well as highly conditioned to the imperatives of the market and external financial institutions (Fischer 2018). Left governments made progress in addressing the tax deficit as a way of enabling higher levels of social spending by taking advantage of the steady economic growth that prevailed in the first decade of the 21 st century which was highly based on the expansion of export-led growth and extraction and exploitation of natural resources (see Radcliffe 2015; Arsel et al 2016). Renewed state activism and state spending sat alongside an increase in commodity prices that between 2002 and 2012 allowed leftist governments to build a revenue with which to redistribute wealth (Jenkins 2012). This involve tax on export and renegotiation of contracts and concessions to foreign investors, especially in the commodity sectors where growth and expansion made a higher tax burden more palatable to them. Social indicators began to show some satisfactory progress. Open unemployment has fallen steadily since 2003. In addition, between 2000 and 2008 the real average salary increased and there were encouraging advances in reducing poverty and destitution: in 2002, poverty affected 44 per cent of the population Latin American; in 2008 it had been reduced to just over 33 per cent (ECLAC 2010).

The irony is that while this model enabled important forms of socio-economic inclusion, it simultaneously undermined more radical transformations. The accelerated pace of natural resource exploitation led to an unprecedented expansion of the extractive and infrastructure frontiers in Latin America (Svampa 2013). Territories that were previously isolated or protected, including environments populated by vulnerable populations, were used for exploitation (Raftopoulos 2017). The increase in the production of gold, carbon and other minerals, as well as soybean and other agroindustries led to critical socio-spatial transformations including existing land uses and land regimes, access to water, and mega projects of infrastructure for production and commercialisation. 
Against this background a diverse range of social conflicts emerged regarding land and indigenous rights, labour practices, and environmental regulations over mining practices and exploitation (Hogenboom 2012; Svampa 2013), particularly in the Andean countries (Bebbington 2012; Bebbington and Bury 2013; Dueholm Rasch 2012; Damonte 2016). As the expansion of extraction necessarily accelerates what David Harvey (2003: 144) calls 'accumulation by dispossession' and, given that the legitimacy function of social policy ran on state rent from extractive activity, the state increasingly become a repressive state, even with a left government in office. As Riofranco (2019) reports, former Ecuadorean leftist President Rafael Correa declared a state of emergency in the province of Morona Santiago in the Amazonian region of Ecuador, deploying troops and national police in response to indigenous Shuar activists' protest against the expansion of mining and the threat posed to their territory and livelihoods. Between 2009 and 2015, three Shuar were killed by state forces while either protesting mining or defending their water rights. Similar repressive responses were seen in Argentina in the province of Formosa linked to the expansion of the soy frontier and landgrabs, that constantly affect the indigenous Qom community in 2010 and in 2012 after popular uprising against megamining in Famatina, a locality in the country's north (Svampa 2017). Brazilian right-wing populist president Jair Bolsonaro's pledge to abolish indigenous reserves and open the land to commercial exploitation has been accompanied by repressive forms against indigenous demands and social mobilisation (Poirier 2019). Even in Bolivia, Evo Morales has found it almost impossible to manage competing identity claims and land rights issues from increasingly vocal and organised indigenous groups. As a result, despite pioneering the most extensive legal recognition of cultural rights, Bolivia has in practice dragged its feet when it comes to granting autonomy to indigenous communities (Grugel and Fontana 2019).

In turn, we started to see two dynamics that undermined post-neoliberal expectations. On the one hand, left-wing governments that could not pay for themselves at the same time as elites were gaining extraordinary power as to oppose further progressive tax reforms. On the other hand, a new dilemma of inclusion crystalised as exploiting natural resources for socio-economic development led to the repoliticisation of the extractive business and a general unwillingness by leaders to consider demands for environmental justice from social actors defending both human and environmental rights, which in some cases fueled repressive legislation and criminalisation of protest, curtailing, 
sometimes violently, rural and indigenous communities and environmental activism (Siegel 2016; Grugel and Fontana 2019).

The explosion of social-environmental conflicts that has accompanied the expansion of extractive activities has posed a challenge to the political and economic ideology of the current socio-development model as well as the 'progressive' stamp that leftist governments created in the regulations and exploitation of natural resources and redirection of revenue for social programmes. Moving forward, there is a question of political economy related to the accentuation of the political authority and power of extractive companies, mainly mining, and landowners, and with it tensions and government, from left and right, that succumbed to that power as they did not managed to put a credible alternative to development and welfare.

But there is also a question of democratic legitimacy in light of social actors that demand environmental and social justice and have been alienated and even repressed in certain cases. Looking back, it is clear that despite some genuinely progressive reforms intended to mitigate the almost unbearable social costs caused by decades of market-led development and austerity, the ambiguities in state approaches to social inclusion has closed off opportunities for substantive democracy.

\section{Conclusion: Social Policy and Persistent Inequalities}

What is the end game that governments try to reach with social policies? Progressive changes in labour markets, social programmes and cash transfers in Latin America led to improvements in terms of citizen inclusion in both a distributive and in a political sense, but these changes have not been embedded in political economies and social political consensus about development and welfare models focused on enforcing the rules of contribution and responsibility. Furthermore, who contributes and who is responsible for not simply addressing unmet material needs of citizens but for changing the power relations (political and economic) that support and reproduce social inequalities and injustices is still source of contention across the region.

Welfare, high-quality public services, the social investment state have always been vulnerable to the capacity of states to offset both the pressures in a capitalist economy and that of greater equality and stability in democratic regimes. Economic growth and resource booms have produced varied, highly contextual models of inclusion with real 
limitations that are unlikely to satisfy the social demands for change. This is not to say that governments have not offered something new in terms of citizenship; the reduction of poverty and inequality, suggest that there have been some successes over the last 15 years. Yet, whether the promise of the Left as a 'post-neoliberal' alternative of governance, affirming alternative modalities of citizen inclusion in the face of markets, and changing the values that underpin production and socially responsible economies, still needs to be scrutinised further.

As this article suggests, the delivery of welfare got stuck in a distributive paradigm that struggled to redefine the terms of neoliberalism despite more imaginative and inclusive approaches to welfare. The post-neoliberal project facilitated the legitimisation of forms of governance for (social) development and the management of natural resources framed in ways that justify not only market-led practices above (some) people's needs but also poverty alleviation programmes delinked from fundamental questions of resource and environmental justice. Governments in Latin America have been successful in refocusing policies to reduce socio-economic inequalities yet at the expense of environmental and identity-based justice. For this reason, this article draws attention to a dark side of targeted and precariously funded welfare regimes that in the region have created tensions between 'socio-economic' and 'ecological' spheres, undermining inclusive citizenship and democracy.

This distinction calls the attention to two main aspects central to this article. Politically, this dark side of welfare in Latin America remains as long as the system disaffects some members of society in support of others. A major challenge for current democracies is how to address poverty and inequality creating conditions in a way that also satisfies human needs without normalising or even legitimising development strategies whose practice leads to the destruction of the environment, damaging our ecosystem. This issue is particularly pressing as the current regional political and ideological compass has changed over the last half decade. New right-leaning governments, such as Piñera in Chile (2010-14), Macri in Argentina (2015- ) and the right wing populist Bolsonaro in Brazil (2018-) have taken office supported by powerful mining and industrial agribusiness, with promises of tax reform, infrastructure and land regulation designed to facilitate agribusiness and mining expansion (Svampa 2013), and by the lower middle classes who were most affected by the economic slowdown for being outsiders in terms of coverage of social policies (particularly CCT) in previous left-leaning administrations 
(Garay 2017). Unsurprisingly, the new right proposes fairly old neoliberal policies that, while not leading to a dismantling of welfare policies, redefines the terms of social policy as efficiency and targeted welfare to mitigate social impact in conditions of austerity. The risk ahead, as suggested in the analysis, is reducing standards of public social provisioning down to their lowest common denominator, neglecting historically and socially-embedded legacies of socio-economic and cultural-environmental injustices that drive exclusionary forms of development and social differentiation.

Thinking about welfare provision this article also draws attention to policy dynamics and funding mechanisms that may support or hinder the political and relational shifts in power necessary to redress structural determinants of poverty and inequality within societies and to transform social relations. The distinction between distributive regimes and social policy as a framework for empowerment and change is linked directly to social welfare regimes in which the rights of citizenship and agency of citizens in current Latin American democracies is practically recognised.

\section{Bibliography}

Amarante, V. and M. Brun (2016) 'Cash transfers in Latin America Effects on poverty and redistribution', WIDER Working Paper 2016/136

Barrientos, A. (2004) 'Latin America: A liberal-informal welfare regime?', in Gough, I. and G. Wood (eds) Insecurity and Welfare Regimes in Asia, Africa and Latin America: Social Policy in Development Contexts Cambridge: Cambridge University Press, 121-68

Barrientos, A. and Hinojosa-Valencia, L. (2009) 'A review of social protection in Latin America', Centre for Social Protection- IDS, Sussex

Bértola, L. and J. A. Ocampo (2012) The Economic Development of Latin America since Independence. Oxford: OUP

Cecchini, S. and B. Atuesta (2017) 'Programas de transferencias condicionadas en América Latina y el Caribe, tendencias de cobertura e inversión’, CEPAL Series Políticas Sociales, 22

Cecchini, S. and F. Veras Soares (2014) 'Cash transfers and health in Latin America', The Lancet, 85, 9975.

Cox, R. (1998) 'The Consequences of Welfare Reform: How Conceptions of Social Rights are Changing', Journal of Social Policy, 27(1): 1-16 
Deacon, B. (2002) Perspectives on Welfare: Ideas, Ideologies and Policy Debates, Buckingham: Open University Press.

Esping-Andersen, G. (1999) Social Foundations of Postindustrial Economies. Oxford University Press

Fultz, E., and J. Francis (2013) 'Cash transfer programmes, poverty reduction and empowerment of women: a comparative analysis: experiences from Brazil, Chile, India, Mexico and South Africa'; International Labour Office. Geneva: ILO

Garay, C. (2017) Social Policy Expansion in Latin America. New York: Cambridge University Press

Grugel, J. and L. Fontana (2019) 'Human Rights and the Pink Tide in Latin America: Which Rights Matter?', Development and Change, 50(3): 707-734,

Grugel, J. and P. Riggirozzi (2012) 'Post-neoliberalism in Latin America: Rebuilding and Reclaiming the State after Crisis', Development and Change, 43 (1): 1-21

Grugel, J. and P. Riggirozzi (2018) 'New directions in welfare: rights-based social policies in post-neoliberal Latin America', Third World Quarterly, 39(3): 527-543

Haggard, S. and R. Kaufman (2008) Development, Democracy, and Welfare States: Latin America, East Asia, and Eastern Europe. Princeton: Princeton University Press

Hall, A. (2008) Brazil's Bolsa Familia: a double-edged sword? Development and change, 39 (5). pp. 799-822.

Handa, S. and B. Davis (2006) 'The Experience of Conditional Cash Transfers in Latin America and the Caribbean', Development Policy Review, 24 (5): 513-536

Hogenboom, B. (2012) 'Depoliticized and Repoliticized Minerals in Latin America', Journal of Developing Studies 28(2): 133-58.

IADB (2006) The Politics of Policies: Economic and Social Progress in Latin America, Report. Washington, DC: Inter-American Development Bank.

ILO (2018) Labour Overview 2018. Lima: ILO

Jenkins, R. (2012) 'Latin America and China:A New Dependency?' Third World Quarterly 33(7) 1338

Lavinas, L. (2018) 'The Collaterization of Social Policy under Finan- cialized Capitalism', Development and Change 49(2): 502-17.

Lewis, C. (2018) 'Post-colonial South America: nineteenth-century laissez faire governance' in P. Riggirozzi and C.Wylde (eds.) Handbook of South American Governance, London: Routledge, 27-44. 
Londono, J.L. and M. Szekely (1997) Distributive Surprises after a Decade of Reforms: Latin America in the 1990s. Washington, DC: IDB

Lustig, N., L. Lopez-Calva, and E. Ortiz-Juarez (2012) 'Declining Inequality in Latin America in the 2000s: the Cases of Argentina, Brazil, and Mexico', ECINEQ WP 2012266. http://www.ecineq.org/milano/WP/ECINEQ2012-266.pdf (Accessed 15 October 2019)

Martínez Franzoni, J. and D. Sánchez-Ancochea (2016). The Quest for Universal Social Policy in the South: Actors, Ideas and Architectures. Cambridge: Cambridge University Press.

Matus-Lopez, M. and C. Cid Pedraza (2016) 'New Long-Term Care Policies in Latin America: The National System of Care in Uruguay', Journal of the American Medical Directors Association, 17(7): 663-5

McGuire, J. (2013). Conditional Cash Transfers in Bolivia: Origins, Impact, and Universality. Paper presented at the Annual Meeting of the International Studies Association, San Francisco, CA.

http://jmcguire.faculty.wesleyan.edu/files/2013/08/McGuire2013cBolivianCCTs.pdf

Molina-Millan, T., T. Barham Karen Macours, J. Maluccio, M. Stampin (2016) 'LongTerm Impacts of Conditional Cash Transfers in Latin America: Review of the Evidence', IDB Working Paper Series 732

Molyneux, M. (2007) 'Change and Continuity in Social Protection in Latin America: Mothers at the Service of the State?', Gender and Development Programme Paper 1, Geneva: UNRISD.

Murat, A., B. Hogenboom and L. Pellegrini (2016) 'The Extractive Imperative in Latin America', The Extractive Industries and Society. Available at http://www.sciencedirect.com/science/journal/2214790X/3 (accessed 15 February 2017)

Nooruddin, I., and N. Rudra (2014) 'Are Developing Countries Really Defying the Embedded Liberalism Compact?' World Politics, 66(4), 603-640

Ocampo, J. A. (2013) The History and Challenges of Latin American Development Santiago: CEPAL

OECD (2017) The Pursuit of Gender Equality: An Uphill Battle, Paris: OECD.

Papadopoulos, T. and R. Velázquez Leyer (2016) 'Two Decades of Social Investment in Latin America: Outcomes, Shortcomings and Achievements of Conditional Cash Transfers', Social Policy and Society 15(3): 435 - 49

Poirier, C. (2019) 'Indigenous Women Mobilize to Resist Bolsonaro', Amazon Watch. Available at https://amazonwatch.org/news/2019/0814-indigenous-women-mobilize-toresist-bolsonaro (Accessed 15 October 2019) 
Portes, A. and K. Hoffman (2003) 'Latin American Class Structures: Their Composition and Change during the Neoliberal Era', Latin American Research Review 38(2): 41-82.

Pribble, J. (2013) Welfare and Party Politics in Latin America. Cambridge: Cambridge University Press

Radcliffe, S. (2015) 'Development Alternatives', Development and Change, 46 (4): 855-74.

Rawlings, L. and G. Rubio (2003) Evaluating the Impact of Conditional Cash Transfer Programs : Lessons from Latin America. Policy Research Working Paper;No. 3119. World Bank, Washington, DC

Saad-Filho, A. (2015) 'Social Policy for Neoliberalism: The Bolsa Família Programme in Brazil', Development and Change 46 (6): 1227-52.

Salvador, S. (2010) Hacia un Sistema Nacional de Cuidados en Uruguay. Santiago de Chile: ECLAC.

Seymour, D. (2014) 'A Human Rights-Based Approach to Social Protection and the Gender Perspective', UNRISD paper.

http://www.unrisd.org/UNRISD/website/newsview.nsf/(httpNews)/F6566C7C57167B1 AC1257CAC00511AB5?OpenDocument (accessed 20 June 2016)

Siegel, K. (2016) 'Fulfilling Promises of More Substantive Democracy? Postneoliberalism and Natural Resource Governance in South America', Development and Change 47 (3): 495-516.

Solimano, A. and R. Soto (2005) Economic Growth in Latin America in the Late Twentieth Century: Evidence and Interpretation. Santiago: Economic Commission for Latin America and the Caribbean.

Stampini, M. and L. Tornarolli (2012) 'The Growth of Conditional Cash Transfers in Latin America and the Caribbean: Did They Go Too Far?, IDB Policy Brief 185. Washington DC: Inter American Development Bank

Svampa, M. (2013) 'Resource Extractivism and Alternatives: Latin American Perspectives on Development', in Lang M. and Dunia Mokrani (eds) Beyond Development: Alternatives Visions from Latin America. Quito: Rosa Luxemburg Foundation, 117-45.

Svampa, M. (2017) ‘¿Del «consenso de los commodities» al «consenso antiindígena»? Viaje al corazón de Vaca Muerta'. Available at http://democraciaglobal.org/maristella-svampa-del-consenso-los-commodities-alconsenso-antiindigena-viaje-al-corazon-vaca-muerta/ (accessed 13 October 2019)

Weyland, K. (2004) 'Neo-liberalism and democracy in Latin America: a mixed record', Latin American Politics and Society 46(1): 135-57 
Zucco, C. (2013) When Payouts Pay Off: Conditional Cash Transfers and Voting Behavior in Brazil 2002-10, American Journal of Political Science, 57(4): 810-822 